\title{
The Role of Courts in Society
}

\author{
edited by \\ SHIMON SHETREET
}

1988, 492 pp.

ISBN 90-247-3670-6

Hardbound Dfl. 225.00/£69.00/\$120.00

Martinus Nijhoff Publishers

The role played by courts in society has increased in many parts of the world. This increased judicial role has meant that the judiciary plays a very significant role in the adjudication of strictly legal matters, as well as, increasingly, in the broader issues of policy making and in constitutional arbitration on important public disputes and political controversies. Interest in the subject is high, and opinions are sharply divided. The Role of Courts in Society offers an analysis of a number of aspects of the judiciary's role: in crisis and in formative periods; the duties and limitations of the judicial function; judges in a democracy: judicial review; judicial selection; meeting the challenge of expeditious justice; and standards of judicial conduct. The work also includes a number of chapters on the role of legal officers who take part in the judicial process, such as the Attorney General, the Public Prosecutor, and the research staff of the appellate courts. International courts are also reviewed: the International Court of Justice, and the Court of Justice of the European Community.

\section{Contributors}

S. Shetreet, P. Hogg, C. F. Forsyth, G. F. Mancini, W. De Vos, X. J. Paparrigopoulos, M. Cappelletti, P. Arens, W. J. Habscheid, M. Landau, N. Redlich, S. Zilberstein, N. Klamaris, B. Neuborne, R. B. McKay, J. Hogarth, S. Shilo, E. A. Thompson, R. S. Thompson, I. Zamir, M. Galanter, $P$. Shuchman, H. Fenge, Z. Segal, S. S. Purvis, T. Franck, A. Barav, M. Darmon, H. A. Blackmun, A. Barak 


\title{
Comparative Law of Monopolies
}

\author{
by \\ Dr DAVID RAYBOULD
}

$1988,800 \mathrm{pp}$.

Looseleaf $£ 145.00 / \mathrm{Dfl}$. 545.00/\$275.00

ISBN 0-86010-941-0

Hardbound £145.00/Dfl. 545.00/\$275.00

ISBN 0-86010-946-1

Graham \& Trotman Limited

This major new looseleaf work examines the laws on restrictive agreements, monopolies and mergers in the jurisdictions of the United States, the United Kingdom, the Federal Republic of Germany, and the European Community. The standards applied in each jursidiction are analysed and the similarities and differences explored in detail. A supplement service will update the Basic Work from Summer 1988.

\section{Contents}

1. Introduction. 2. National Laws of Monopoly. USA: Summary of Antitrust Laws; Sherman Act; Clayton Act; Federal Trade Commission Act; Robinson-Patman Act; Monopolisation; Mergers; Interlocking Directorates; Joint Ventures; Jurisdictional Aspects. EEC: Competition Laws; Article 85; Joint Ventures; Article 86; Mergers. Germany: Substantive Provisions; Control of Market Dominance; Merger Control. UK: Substantive Provisions; Monopolies; Merger Control, Competition Act. 3. Comparative Evaluation of Anti-Monopoly Laws in the 4 Jurisdictions Monopolies; Mergers; Joint Ventures; Transnational Aspects. 


\title{
Aviation Antitrust
}

\section{The Extraterritorial Application of the United States Antitrust Laws and International Air Transportation \\ by}

\author{
PATRICIA M. BARLOW
}

1988, $256 \mathrm{pp}$.

ISBN 90-6544-293-6

Paperback Dfl. 125.00/£38.50/US $\$ 66.50$

Kluwer Law and Taxation Publishers

This book deals with a new field of antitrust law which has gained prominence following the United States deregulation of its air transportation industry. The author links this development with the extraterritorial application of the United States antitrust laws and the response to this. Chapters are marked by detailed legal analyses of statutes, treaties and case law and the book is very practical in its approach, with relevant rules of procedure both within and outside the United States being discussed in detail. Historically the relationship between the antitrust laws and the air transportation industry is first outlined during both the regulated and then during the deregulated era. The relevant antitrust statutes are outlined with emphasis on their application in the air transportation context together with some discussion of antitrust-sensitive industrial practices. The book then focuses on the question of extraterritoriality. Personal and subject matter jurisdiction are outlined, followed by a detailed discussion of the defenses available to an antitrust litigant in international air tranportation. The special discovery and enforcement difficulties confronting such a litigant are analyzed, including reference to the various blocking statutes, together with a discussion of the Laker Airways litigation. The author addresses the question of antitrust dispute resolution including the question of arbitrating international aviation antitrust issues.

Bringing together in one volume the laws of the United States and elsewhere, this book will provide practising attorneys, airline executives, international organizations and students with a detailed overview of the application of this composite body of laws in international air transportation.

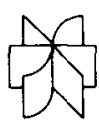

Kluwer Academic Publishers

P.O. Box 989,3300 AZ Dordrecht, The Netherlands 101 Philip Drive, Norwell, MA 02061, U.S.A.

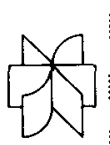

